\title{
Calcium lactate and salicylic acid foliar application influence eggplant growth and postharvest quality parameters
}

\author{
Zahra GHAHREMANI ${ }^{1, *}$, Masoud NOROUZI ${ }^{1}$, Taher BARZEGAR ${ }^{1}$ and Mohammad Ebrahim \\ RANJBAR $^{1}$
}

Received February 27, 2020; accepted April 18, 2021. Delo je prispelo 27. februarja 2020, sprejeto 18. aprila 2021.

\begin{abstract}
Calcium lactate and salicylic acid foliar application influence eggplant growth and postharvest quality parameters

Abstract: Eggplant is one of the most popular and vital vegetable crops in the world. Various plant bio-regulators have been used in different crops to increase uptake of nutrients thereby leading to improvement in growth, flowering, fruit quality, storability and yield. The scope of this study was to evaluate the effects of calcium lactate and salicylic acid foliar application on growth parameters, physiological characteristics and shelf-life of eggplant fruit. Obtained results showed that the highest applied concentrations of calcium lactate $(4 \mathrm{mM}$ or 0.8 $\left.\mathrm{g} \mathrm{l}^{-1}\right)$ and salicylic acid $\left(1.5 \mathrm{mM}\right.$ or $\left.0.2 \mathrm{~g} \mathrm{l}^{-1}\right)$ foliar application led to the highest values of measured growth parameters and yield. Applying of calcium lactate and salicylic acid foliar treatments could increase tissue firmness and ascorbic acid content of fruits. Foliar application of calcium lactate $4 \mathrm{mM}\left(0.8 \mathrm{~g} \mathrm{l}^{-1}\right)$ and salicylic acid $1 \mathrm{mM}\left(0.13 \mathrm{~g} \mathrm{l}^{-1}\right)$ was the best treatment to decrease percentage of fruit decay. In conclusion, our results showed that foliar application of calcium lactate and salicylic acid can be useful and inexpensive treatment to improve growth parameters, physiological characteristics and post-harvest properties of eggplant fruit.
\end{abstract}

Key words: eggplant; calcium sources; chlorophyll content; foliar spraying; post-harvest fruit characteristics; salicylic acid.
Foliarno dodajanje kalcijevega laktata in salicilne kisline vpliva na rast jajčevca in na obstojnost plodov pri shranjevanju

Izvleček: Jajčevec je v svetovnem merilu ena izmed najbolj popularnih plodovk. Pri pridelavi različnih kulturnih rastlin so bili uporabljeni razni bioregulatorji privzema hranil, kar bi vodilo $\mathrm{k}$ izboljšanju rasti, cvetenja, kakovosti plodov, povečanju pridelka in trajnosti pri shranjevanju. Namen te raziskave je bil ovrednostiti učinke foliarnega dodajanja kalcijevega laktata in salicilne kisline na rastne parametre, fiziološke lastnosti in trajanje plodov pri shranjevanju. Dobljeni izsledki so pokazali, da sta imeli največji foliarni dodajanji kalcijevega laktata $(4 \mathrm{mM}$ ali $\left.0,8 \mathrm{~g} \mathrm{l}^{-1}\right)$ in salicilne kisline $\left(1,5 \mathrm{mM}\right.$ ali $\left.0,2 \mathrm{~g}^{-1}\right)$ največji učinek na vrednosti merjenih rastnih parametrov in velikosti pridelka. Foliarano obravnavanje s kalcijevim laktatom in salicilno kislino bi lahko povečalo čvrstost tkiv in vsebnost askorbinske kisline v plodovih. Foliarno dodajanje kalcijeva laktata $4 \mathrm{mM}$ $\left(0,8 \mathrm{~g} \mathrm{l}^{-1}\right)$ in salicilne kisline $1 \mathrm{mM}\left(0,13 \mathrm{~g} \mathrm{l}^{-1}\right)$ je bilo najboljše obravnavanje za zmanjševanje odstotka propadlih plodov. Zaključimo lahko, da so ti izsledki pokazali, da bi lahko bilo foliarno dodajanje kalcijeva laktata in salicilne kisline uporaben in poceni postopek za izboljšanje rastnih parametrov, fiziološki lastnosti in lastnosti plodov jajčevca pri shranjevanju.

Ključne besede: jajčevec; vir kalcija; vsebnost klorofila; foliarno gnojenje; lastnosti plodov pri shranjevanju; salicilna kislina

1 Department of Horticulture, Faculty of Agriculture, University of Zanjan, Zanjan, Iran. I.R.

* Corresponding author's e-mail: z.ghahremani@znu.ac.ir 


\section{INTRODUCTION}

Eggplant (Solanum melongena L.) is one of the most popular and vital vegetable crops in the world (Kaushik, 2019). Various plant bio-regulators have been used in different crops to increase uptake of nutrients thereby leading to improvement in growth, flowering, fruit quality, storability and yield (Ranjbar et al., 2017; Mustafavi et al., 2018; Ghahremani et al., 2020). However, recently new plant growth regulators like salicylic acid (SA) and calcium lactate (CL) have been found beneficial in maintaining balance between vegetative and reproductive growth andincreasing the uptake of nutrients thereby resulting in high yield of superior quality crops with prolonged storability and consistent bearing (Shaarawi et al., 2016). Calcium $\left(\mathrm{Ca}^{2+}\right)$ has been extensively studied both as an essential element and for its potential role in maintaining postharvest quality of fruit and vegetable crops by contributing to the linkage between pectic substances within the cell wall. CL treatment reduced the respiration rate and improved the firmness of persimmon slices (Youssef et al., 2017). SA is one of the groups of common phenolic compounds that are produced naturally by plants, which can act as endogenous plant growth regulator. Its application might be safe and more useful for plant growth improving. SA stimulates the growth and development of roots of the treated plants (by increasing of $\mathrm{H}^{+}$-ATPase activity and root ATP content) thereby improving nutrient uptake (Ghassemi-Golezani and Farhangi-Abriz, 2018). Enhancement of chlorophyll and carotenoid pigments levels, photosynthetic rate and modifying the activity of some of the important enzymes are other roles assigned to SA. It induces specific changes in leaf anatomy and chloroplast structure (Uzunova and Popova, 2000). The effect of postharvest calcium chloride (CC) and SA applications on shelf-life and quality attributes of kiwifruits were evaluated by Kazemi et al. (2011). Results of this experiment showed that post-harvest SA and CC treatments prevented fruit softening and decreased mass loss of fruits. Also in the other experiment, the effect of pre-harvest CC application on post-harvest life and quality of peach fruits was studied. $0.5 \%, 1.0 \%$ and $1.5 \%$ of CC solutions were sprayed on peach plants and CC $1.5 \%$ resulted in maximum fruit firmness, sensory quality score and calcium content during the storage period.

The scope of the present research was to investigate the effects of CL and SA foliar application on growth parameters, several fruit quality attributes such as tissue firmness, ascorbic acid content and total soluble solids of fruits and some of the most important post-harvest properties of eggplant fruit such as titratable acidity, fruit mass loss, fruit decay and browning of pulp tissue.

\section{MATERIALS AND METHODS}

The experiment was conducted in University of $\mathrm{Za}$ njan, Zanjan, Iran in 2018-2019. Soil samples of experimental farm were collected from a depth of 0 to $60 \mathrm{~cm}$ andthen analyzed. Table 1 shows the measured characteristics of experimental farm soil. Also, Table 2 shows quality and chemical properties of applied irrigation water.

Table 1: Physical and chemical properties of experimental farm soil

\begin{tabular}{lccccc}
\hline $\begin{array}{c}\text { Clay } \\
(\%)\end{array}$ & $\begin{array}{r}\text { Silt } \\
(\%)\end{array}$ & $\begin{array}{c}\text { Sand } \\
(\%)\end{array}$ & $\begin{array}{c}\text { Soil } \\
\text { texture }\end{array}$ & $\begin{array}{c}\text { Organic matter } \\
(\%)\end{array}$ & $\mathrm{K}\left(\mathrm{g} \mathrm{kg}^{-1}\right)$ \\
\hline 37 & 38 & 25 & $\begin{array}{c}\text { Clay } \\
\text { loam }\end{array}$ & 0.94 & 0.2 \\
\hline \multicolumn{5}{c}{} \\
\hline $\mathrm{Na}\left(\mathrm{g} \mathrm{kg}^{-1}\right)$ & $\mathrm{Ca}\left(\mathrm{g} \mathrm{kg}^{-1}\right)$ & $\mathrm{N}(\%)$ & $\mathrm{EC}\left(\mathrm{dS} \mathrm{m}^{-1}\right)$ & $\mathrm{pH}$ \\
\hline 0.13 & 0.12 & 0.07 & 1.49 & 7.4 \\
\hline
\end{tabular}

Table 2: Quality and chemical properties of applied irrigation water

\begin{tabular}{ccccc}
\hline $\begin{array}{c}\mathrm{SO}_{4}{ }^{2} \\
\left(\mathrm{mg} \mathrm{l}^{-1}\right)\end{array}$ & $\begin{array}{c}\mathrm{HCO}_{3}{ }^{-} \\
\left(\mathrm{mg} \mathrm{l}^{-1}\right)\end{array}$ & $\begin{array}{c}\mathrm{CO}^{2-} \\
\left(\mathrm{mg} \mathrm{l}^{-1}\right)\end{array}$ & $\begin{array}{c}\mathrm{Cl} \\
\left(\mathrm{mg} \mathrm{l}^{-1}\right)\end{array}$ & $\begin{array}{c}\mathrm{Mg} \\
\left(\mathrm{mg} \mathrm{l}^{-1}\right)\end{array}$ \\
\hline 550.5 & 159 & 0.0 & 435.3 & 241.6 \\
\hline $\begin{array}{c}\mathrm{Ca} \\
\left(\mathrm{mg} \mathrm{l}^{-1}\right)\end{array}$ & $\begin{array}{c}\mathrm{K} \\
\left(\mathrm{mg} \mathrm{l}^{-1}\right)\end{array}$ & $\begin{array}{c}\mathrm{Na} \\
\left(\mathrm{mg} \mathrm{l}^{-1}\right)\end{array}$ & $\begin{array}{c}\mathrm{EC} \\
\left(\mathrm{dS} \mathrm{m}^{-1}\right)\end{array}$ & $\mathrm{pH}$ \\
\hline 400 & 2.74 & 152 & 2.7 & 7.2 \\
\hline
\end{tabular}

\subsection{PLANT MATERIAL}

Eggplant seeds (IR3121 cultivar) were sawn in peat moss at controlled condition $\left(23 \pm 2{ }^{\circ} \mathrm{C}\right.$ temperature and 60 to $70 \%$ relative humidity). Seedlings were transplanted to the field in 4-5 leaf stage (in May) at a distance of $60 \mathrm{~cm}$ between rows and $50 \mathrm{~cm}$ between plants. Seedlings were immediately irrigated after planting and then were watered by using of drip irrigation every 3 days. Weeds were controlled by hand weeding. Eggplant fruits were harvested at full ripening stage. Harvested fruits were stored at cold storage $\left(10{ }^{\circ} \mathrm{C}\right.$ temperature and $85 \pm 5 \%$ relative humidity) for 30 days. Post-harvest characteristics evaluation was performed during storage at 10-day intervals. 


\subsection{METHODS}

\subsubsection{Growth parameters and yield}

Number of fruit per plant, diameter of fruit, height of plant, average mass of fruit, length of fruit, leaf area and yield were measured as growth parameters in harvest stage. Average mass of fruit was recorded by using digital scale (EK3000I). Leaf area was measured by using digital scanner (E84-10017) and imageJ software (V3).

\subsubsection{Physiological characteristics}

Total chlorophyll and carotenoid content, titratable acidity, tissue firmness, ascorbic acid and total soluble solids of fruits were measured as physiological characteristics. Total chlorophyll and carotenoid content of leaves was determined by measuring absorption with a spectrophotometer at 645 and $663 \mathrm{~nm}$ for chlorophyll content and 480 and $510 \mathrm{~nm}$ for carotenoid content (spectrophotometer-SAFAS UVmc2) as described by Arnon (1967). For evaluating of titratable acidity, tissue of eggplant fruit $(10 \mathrm{~g})$ was homogenized in $40 \mathrm{ml}$ distilled water and filtered to extract the juice. 2 to 5 drops of phenolphthalein were added in this juice. A $10 \mathrm{ml}$ aliquot was taken in a titration flask and titrated against $0.1 \mathrm{~N} \mathrm{NaOH}$ till permanent light pink color appeared. Three consecutive readings were taken from each replication of a treatment and percent acidity as malic acid was calculated by using the following formula:

$\% \mathrm{TA}=[\mathrm{E} \times \mathrm{N} \times \mathrm{S} \times \mathrm{F} / \mathrm{C}] \times 100 \quad$ (Raja et al. 2105). (E: Equivalent wt. of malic acid) (N: Normality of $\mathrm{NaOH}$ ) (S: $\mathrm{ml} \mathrm{NaOH}$ used) (F: vol. of aliquot taken) (C: wt. of sample).

Fruit firmness was measured with penetrometer (FT-327-48011-Alfonsine-Italy) and expressed pressure necessary to force a plunger of $11 \mathrm{~mm}$ size into the fruit (Arvanitoyannis et al., 2005). Ascorbic acid content of fruit was determined by applying of iodometric titration method according to Vanderslice et al. (1990). Total soluble solids was evaluated by using refractometer (ATAGO Brixo-32) and expressed as degrees brix (Paull and Chen, 1989).

\subsubsection{Post-harvest characteristics}

Following properties were analyzed to evaluate post-harvest characteristics of eggplant fruits (during storage): titratable acidity, tissue firmness, ascorbic acid, soluble solids content, fruit mass loss, fruit decay and browning of pulp tissue.

Fruit mass loss: Mass loss was determined by the following formula: Mass loss $(\%)=[(\mathrm{A}-\mathrm{B}) / \mathrm{A}] \times 100$
Where $\mathrm{A}$ indicates the fruit mass at the time of harvest and $\mathrm{B}$ indicates the fruit mass after storage intervals (Huang et al., 2000).

Fruit decay: Fruit decay percent was estimated by visual scoring method, as described by Kader et al. (2010) on 1-4 scale, with reference points of: 4 = severe; $3=$ moderate; 2 = slight $1=$ none. The score attribution depends on morphological effects such as color change, microorganism effects and smell.

Browning of pulp tissue: The color parameter $\mathrm{L}^{*}$ indicates the lightness of color $(0=$ black and $100=$ white). A Minolta Colorimeter model CR-300 was used to determine $L^{*}$, and the readings were taken soon after slicing the central section of each fruit (thickness $=0.5$ $\mathrm{cm}$ ). All measurements were done on three fruits from each condition and by duplicate. The results were expressed as $\mathrm{L}_{0}$, values higher than 86 denotes whitish pulp and values between 81 and 82 show only seed browning. Lightness near to 78 indicates an incipient browning of seed and pulp, while values below 73 denote considerable browning of seed and pulp (Ahmad et al., 2013).

\subsection{STUDY DESIGN}

Factorial experiment was laid out based on randomized complete blocks design (to evaluate growth parameters and physiological characteristics in harvest stage) and completely randomized design (to evaluate postharvest characteristics during storage) with three replications. The factors are foliar application of CL and SA in different concentrations including three levels for CL solution: $0 \mathrm{mM}$ (control), $2 \mathrm{mM}\left(0.4 \mathrm{~g} \mathrm{~L}^{-1}\right)$ and $4 \mathrm{mM}(0.8$ $\mathrm{g} \mathrm{L}^{-1}$ ) and three levels for SA solution: $0 \mathrm{mM}$ (control), $1 \mathrm{mM}\left(0.13 \mathrm{~g} \mathrm{~L}^{-1}\right)$ and $1.5 \mathrm{mM}\left(0.2 \mathrm{~g} \mathrm{~L}^{-1}\right)$ and also during of storage in three levels including: 10, 20 and 30 days. CL and SA foliar application was carried out at 6-leaf stage for the first time and continued at 10-day intervals until harvest stage.

\subsection{STATISTICAL ANALYSIS}

Data were analyzed by analysis of variance (ANOVA) using the SAS software (V9). Mean comparisons were performed by Duncan's multiple range test at confidence level of $95 \%$. 


\section{RESULTS AND DISCUSSION}

\subsection{GROWTH PARAMETERS AND YIELD}

According to ANOVA analysis, significant influence of CL and SA foliar application and interaction between them on all of measured growth parameters was found. Table 3 shows, the highest applied concentrations of CL $(4 \mathrm{mM})$ and SA $(1.5 \mathrm{mM})$ foliar application led to the highest values in all of measured growth parameters. Also, the highest value of yield $\left(127.21 \mathrm{tha}^{-1}\right)$ was recorded in plants sprayed by CL $4 \mathrm{mM}$ and SA $1.5 \mathrm{mM}$. Yield increased by $13.46 \%$ at sprayed plants by CL $4 \mathrm{mM}$ and SA $1 \mathrm{mM}$ compared to CL $2 \mathrm{mM}$ and SA $1 \mathrm{mM}$ treated plants. Similar stimulatory effects of SA and different types of calcium sources (calcium oxide, calcium chloride, calcium chelate and calcium lactate) on different growth parameters were reported in tomato (Rab \& Haq, 2012), strawberry (Kazemi, 2013a), cucumber (Kazemi, 2013b), cowpea (Mohamed \& Basalah, 2015) and lettuce (Almeida et al., 2016; Khani et al., 2020). SA stimulates the growth and development of roots of the treated plants by increasing of $\mathrm{H}^{+}$-ATPase enzyme activity and root ATP content (Ghassemi-Golezani and Farhangi-Abriz, 2018) thereby improving nutrient uptake. So, increasing of nutrient uptake rate can be as important reason for increasing of growth parameters and yield in SA treated plants. According to Hepler (1994), the effects of different calcium sources on growth parameters of different crops can be related to the fact that calcium ions $\left(\mathrm{Ca}^{2+}\right)$ appeared to participate in the regulation of different aspects of cell division. Calcium is one of the most important ions in formation of the mitotic spindle which directly affects cell division.

\subsection{PHYSIOLOGICAL CHARACTERISTICS}

All of the measured physiological characteristics were significantly affected by CL and SA foliar application and interaction between them. The highest chlorophyll content $\left(1.32 \mathrm{mg} \mathrm{g} \mathrm{FM}^{-1}\right)$ was related to sprayed plants by CL $4 \mathrm{mM}$ and SA $1 \mathrm{mM}$ and the lowest carotenoid content $\left(0.36 \mathrm{mg} \mathrm{g} \mathrm{FM}^{-1}\right)$ was obtained in control (sprayed plants by CL $0 \mathrm{mM}$ and SA $0 \mathrm{mM}$ ) (Table 4). Foliar application of SA was found to increase the chlorophyll content in cowpea (Chandra \& Bhatt, 1998), tomato (Kalarani et al., 2002), cucumber (Yildirim et al., 2008) and strawberry (Karlidag et al., 2009a, 2009b). MartinDiana et al. (2005), reported that carotenoid levels were higher in CL-treated carrots than that in control samples at the end of 10 days storage. Results showed that, the highest and lowest values of total soluble solids were related to control fruits (harvested from sprayed plants by CL $0 \mathrm{mM}$ and SA $0 \mathrm{mM}$ ) and harvested fruits from CL 4 $\mathrm{mM}$ and SA $0 \mathrm{mM}$ sprayed plants, respectively. Foliar application of CL and SA led to a significant reduction in total soluble solids of fruits. Different results were reported about effect of calcium sources on total soluble solids of fruits, for instance, according to Akhtar et al. (2010), CC treatment could significantly increase total soluble solids in Loquat fruit but in contrast, Dong et al. (2004) reported that, total soluble solids of tomato reduced by employing of calcium treatment. Calcium sources and SA treatments lead to a decrease in respiration rate, ethylene biosynthesis and ripening of fruits, which in turn decrease the polysaccharide degradation in cell wall and cell membrane. So, decreasing of polysaccharide degradation can lead to a reduction of total soluble solids of fruits.

Titratable acidity increased by $2.86 \%$ at harvested fruits from CL $4 \mathrm{mM}$ and SA $1.5 \mathrm{mM}$ sprayed plants compared to fruits of treated plants by CL $4 \mathrm{mM}$ and SA $0 \mathrm{mM}$. Applying of CL and SA foliar treatment could increase tissue firmness and ascorbic acid content of fruits and CL $4 \mathrm{mM}$ and SA $1.5 \mathrm{mM}$ foliar spraying was the best treatment to increase tissue firmness and ascorbic acid content of eggplant fruits. Fruit softening results from cell wall degradation by cell wall hydrolases such as polygalactosidases, pectin methylesterases, b-galactosidase and xylanase along with cell membrane deterioration. As an ethylene inhibitor, SA delays fruit ripening and prevents fruit softening by reducing the activity of cell wall-degrading enzymes. Srivastava and Dwivedi (2000) reported that SA reduced polygalactosidases, xylanase, and cellulase enzyme activity in harvested banana fruits. Wang et al. (2006) reported that SA treatment can increase ascorbic acid content in fruit and vegetable crops by increasing of ascorbate peroxidase enzyme activity. Our finding with respect to the effect of CL and SA foliar application on ascorbic acid content is in line with those reported by Elvwan and Hamahyomy (2009). They observed an increase in ascorbic acid content of greenhouse pepper by employing of low concentration of SA foliar application. 
Table 3: Effect of CL and SA foliar application on growth parameters and yield at harvest

\begin{tabular}{|c|c|c|c|c|c|c|c|c|}
\hline $\begin{array}{c}\text { SA } \\
\text { concentration } \\
(\mathrm{mM})\end{array}$ & $\begin{array}{c}\mathrm{CL} \\
\text { concentration } \\
(\mathrm{mM})\end{array}$ & $\begin{array}{l}\text { Leaf area } \\
(\mathrm{mm})\end{array}$ & $\begin{array}{c}\text { Average mass } \\
\text { of fruits (g) }\end{array}$ & $\begin{array}{l}\text { Number } \\
\text { of fruit per } \\
\text { plant }\end{array}$ & $\begin{array}{l}\text { Diameter of } \\
\text { fruit }(\mathrm{cm})\end{array}$ & $\begin{array}{l}\text { Length of } \\
\text { fruit }(\mathrm{cm})\end{array}$ & $\begin{array}{l}\text { Height of } \\
\text { plant }(\mathrm{cm})\end{array}$ & Yield $\left(\mathrm{t} \mathrm{ha}^{-1}\right)$ \\
\hline \multirow{4}{*}{0} & 0 & $185.4 \mathrm{f}$ & $255.66 \mathrm{f}$ & $11.23 \mathrm{~g}$ & $3.54 \mathrm{f}$ & $19.35 f$ & $63.11 \mathrm{~h}$ & $95.57 \mathrm{~g}$ \\
\hline & 2 & $192.32 d$ & $262.66 \mathrm{e}$ & $11.41 \mathrm{f}$ & $3.65 \mathrm{e}$ & $19.73 \mathrm{ef}$ & $64.21 \mathrm{~g}$ & $99.72 \mathrm{f}$ \\
\hline & 4 & $196.12 \mathrm{c}$ & $275.66 c$ & $12.03 \mathrm{c}$ & $3.83 \mathrm{~d}$ & $20.12 \mathrm{e}$ & $66.59 \mathrm{e}$ & $110.06 \mathrm{c}$ \\
\hline & 0 & $191.59 \mathrm{~d}$ & $269.33 \mathrm{~d}$ & $11.64 \mathrm{e}$ & $3.84 \mathrm{~d}$ & $21.47 \mathrm{~d}$ & $65.42 \mathrm{f}$ & $104.16 \mathrm{e}$ \\
\hline \multirow[t]{3}{*}{1} & 2 & $195.29 c$ & $273.66 c$ & $11.05 \mathrm{~h}$ & $3.94 \mathrm{c}$ & $22.57 b c$ & $67.39 \mathrm{e}$ & $100.31 \mathrm{f}$ \\
\hline & 4 & $199.19 b$ & $280 \mathrm{~b}$ & $12.43 \mathrm{~b}$ & $4.25 \mathrm{~b}$ & $23.28 \mathrm{~b}$ & $72.59 c$ & $115.89 b$ \\
\hline & 0 & $188.64 \mathrm{e}$ & $274 \mathrm{c}$ & $11.82 \mathrm{~d}$ & $3.82 \mathrm{~d}$ & $21.60 \mathrm{~d}$ & $70.03 d$ & $107.48 \mathrm{~d}$ \\
\hline \multirow[t]{2}{*}{1.5} & 2 & $200.89 b$ & $282.66 \mathrm{~b}$ & $12.38 \mathrm{~b}$ & $3.91 \mathrm{c}$ & $22.40 \mathrm{c}$ & $74.18 \mathrm{~b}$ & $115.42 b$ \\
\hline & 4 & $207.45 a$ & $297.33 a$ & $12.84 \mathrm{a}$ & $4.42 \mathrm{a}$ & $24.08 \mathrm{a}$ & $81.77 \mathrm{a}$ & $127.21 \mathrm{a}$ \\
\hline
\end{tabular}

Values in columns for same variable followed by the same letter are not significantly different according to Duncan's multiple range test $(p \leq 0.05)$

Table 4: Effect of CL and SA foliar application on the content of metabolites and firmness at harvest

\begin{tabular}{|c|c|c|c|c|c|c|c|}
\hline $\begin{array}{c}\text { SA } \\
\text { concentration } \\
(\mathrm{mM})\end{array}$ & $\begin{array}{c}\mathrm{CL} \\
\text { concentration } \\
(\mathrm{mM})\end{array}$ & $\begin{array}{l}\text { Chlorophyll } \\
\text { content } \\
\left(\mathrm{mg} \mathrm{g} \mathrm{FM}^{-1)}\right.\end{array}$ & $\begin{array}{c}\text { Carotenoid } \\
\text { content } \\
\left(\mathrm{mg} \mathrm{g} \mathrm{FM}^{-1)}\right.\end{array}$ & $\begin{array}{c}\text { Total soluble } \\
\text { solids }(0 \mathrm{~B})\end{array}$ & $\begin{array}{c}\text { Titratable } \\
\text { acidity (\%) }\end{array}$ & $\begin{array}{l}\text { Tissue firmness } \\
\text { (N) }\end{array}$ & $\begin{array}{l}\text { Ascorbic acid } \\
\text { content (mg } \\
100 \mathrm{~g} \text { Juice) }\end{array}$ \\
\hline \multirow{4}{*}{0} & 0 & $0.80 \mathrm{~h}$ & $0.36 \mathrm{~h}$ & $5.07 \mathrm{a}$ & $5.45 \mathrm{e}$ & $3.23 \mathrm{f}$ & $1.75 \mathrm{e}$ \\
\hline & 2 & $0.93 \mathrm{f}$ & $0.39 \mathrm{~g}$ & $4.87 \mathrm{~b}$ & $5.47 \mathrm{de}$ & $2.76 \mathrm{ef}$ & $1.70 \mathrm{e}$ \\
\hline & 4 & $1.25 \mathrm{c}$ & $0.45 \mathrm{~d}$ & $4.18 \mathrm{~g}$ & $5.44 \mathrm{e}$ & $2.64 c$ & $1.83 \mathrm{~d}$ \\
\hline & 0 & $1.01 \mathrm{e}$ & $0.42 \mathrm{f}$ & $4.78 c$ & $5.49 \mathrm{~cd}$ & $3.00 \mathrm{~d}$ & $1.82 \mathrm{~d}$ \\
\hline \multirow[t]{3}{*}{1} & 2 & $1.05 \mathrm{~d}$ & $0.44 \mathrm{e}$ & $4.67 \mathrm{~d}$ & $5.50 \mathrm{bcd}$ & $3.37 \mathrm{~b}$ & $1.90 \mathrm{c}$ \\
\hline & 4 & $1.32 \mathrm{a}$ & $0.51 \mathrm{c}$ & $4.46 \mathrm{e}$ & $5.52 \mathrm{~b}$ & $3.41 \mathrm{ab}$ & $1.94 \mathrm{bc}$ \\
\hline & 0 & $0.87 \mathrm{~g}$ & $0.39 \mathrm{~g}$ & $4.82 \mathrm{bc}$ & $5.52 \mathrm{bc}$ & 2.92de & $1.90 \mathrm{c}$ \\
\hline \multirow[t]{2}{*}{1.5} & 2 & $0.94 \mathrm{f}$ & $0.62 \mathrm{a}$ & $4.53 \mathrm{e}$ & $5.53 \mathrm{~b}$ & $3.29 b c$ & $1.99 \mathrm{~b}$ \\
\hline & 4 & $1.29 \mathrm{~b}$ & $0.59 b$ & $4.34 \mathrm{f}$ & $5.60 \mathrm{a}$ & $3.54 \mathrm{a}$ & $2.07 \mathrm{a}$ \\
\hline
\end{tabular}

Values in columns for same variable followed by the same letter are not significantly different according to Duncan's multiple range test $(p \leq 0.05)$

\subsection{POST-HARVEST CHARACTERISTICS}

According to ANOVA analysis, all of the measured post-harvest characteristics except fruit decay were affected by interaction between CL and SA foliar application and duration of storage.

Figure 1 shows the effect of interaction between CL and SA treatment and duration of storage on total soluble solids, titratable acidity, tissue firmness and ascorbic acid content of fruits. Total soluble solids of fruits raised by increasing the time of storage from 10 to 20 days but a reverse trend (reduction) was detected in total soluble solids of fruits from 20 to 30 days of storage. In our opinion, change in ratio of respiration rate (consumption of sugars) to conversion of starch to sugar (production of sugars) would be a main reason on increasing of total soluble solids in first days of storage with a peak on 20 days of storage and then decreasing until 30 days after storage. The rate and speed of conversion of starch to sugar (production of sugars) is higher than respiration rate (consumption of sugars) in first days of storage and it can lead to a significant increase in total soluble solids of fruits 
but the ratio of respiration rate to conversion of starch to sugar increased after 20 days of storage, so a significant decrease was detected in total soluble solids of fruits in the last days of storage. (Figure 1a). The highest value of titratable acidity (5.53 \%) was obtained in harvested fruits from sprayed plants by CL $4 \mathrm{mM}$ and SA $1.5 \mathrm{mM}$ after 10 days of storage (Figure 1b). During storage, there is conversion of starch to sugar and the oxidation of organic acids to sugar which rapidly reduce the titratable acidity and increase total soluble solids of fruits (Campestre et al., 2002). Tissue firmness reduced by increas- ing the time of storage but harvested fruits from treated plants showed higher value of tissue firmness than that in control (Figure 1C). According to Mahajan et al. (2017), the reduction of fruit firmness during post-harvest stage is mainly caused due to the dissolution of the middle lamella, decreasing of cell-to-cell adhesion and the weakening of parenchyma cell walls as a result of the action of cell wall modifying enzymes leading to shriveling and softening. We guess the inhibitory effect of CL and SA on degrading enzymes activity can be as main reason for positive effect of foliar treatment on fruit tissue firmness
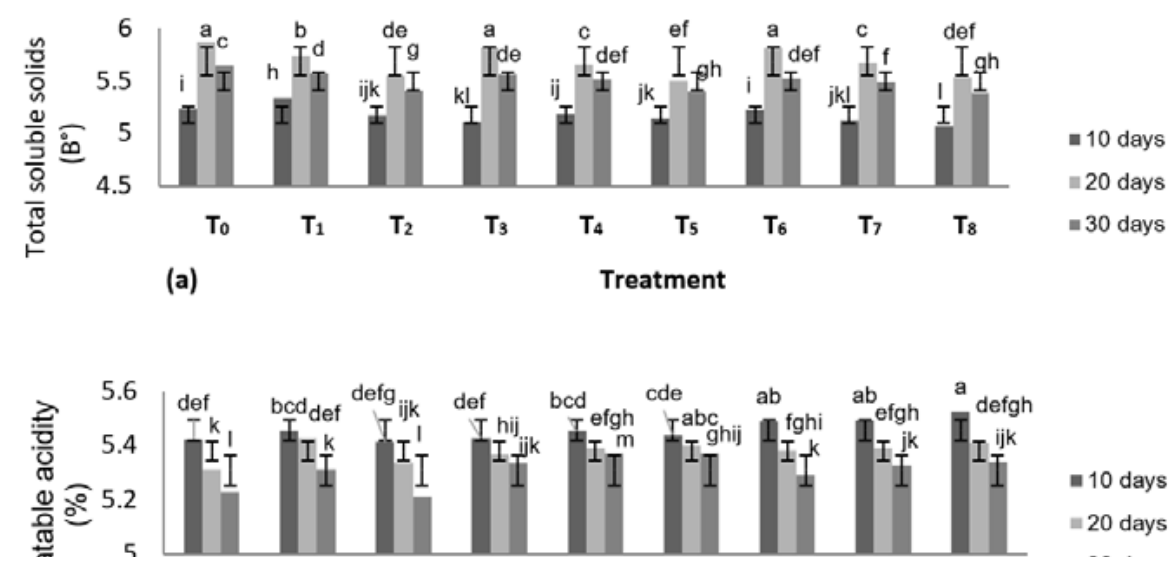

(b) Treatment

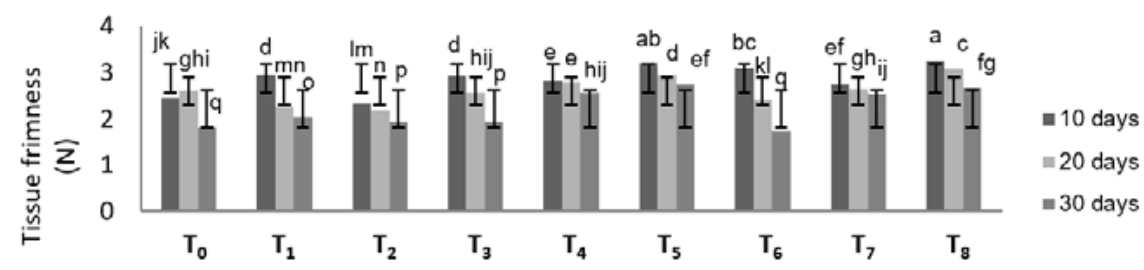

(c)

Treatment

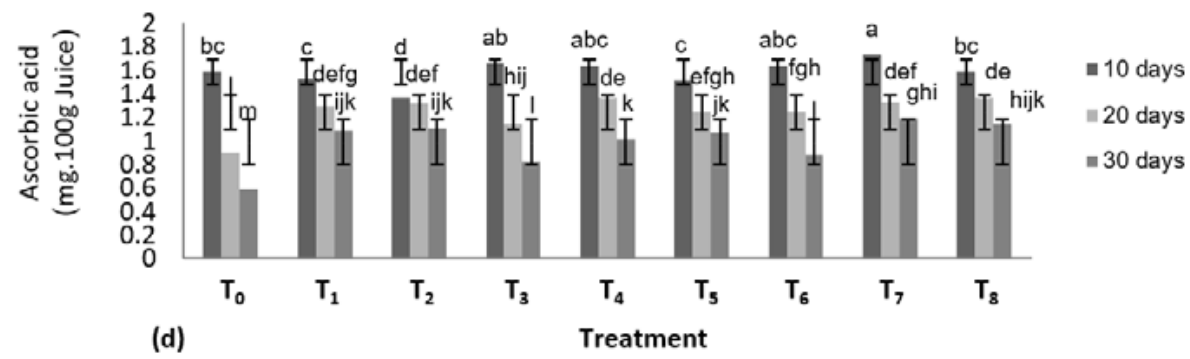

Figure 1: Effect of CL and SA foliar application and during of storage on: a total soluble solids, b titratable acidity, $c$ tissue firmness and $\mathrm{d}$ ascorbic acid content

Values in columns for same variable followed by the same letter are not significantly different according to Duncan's multiple range test $(\mathrm{p} \leq 0.05)$ 
in this study. The highest and lowest values of ascorbic acid content were related to harvested fruits from CL 2 $\mathrm{mM}$ and SA $1.5 \mathrm{mM}$ sprayed plants after 10 days of storage and control fruits after 30 days of storage (1.78 and $0.58 \mathrm{mg} .100 \mathrm{~g}$ juice, respectively) (Figure 1d). Our results showed that ascorbic acid content of fruits reduced by increasing of duration of storage but foliar treatment led to a reduction in ascorbic acid decreasing rate. According to Umebese and Bankole (2013), SA foliar application can increase nitrate reductase enzyme activity and this enhancement corresponds with the reduction of ascorbic acid decreasing rate.

Figure 2 shows the effect of CL and SA treatment and duration of storage on pulp tissue browning and fruit mass loss. The highest and lowest values of pulp tissue browning were related to control fruits after 30 days of storage and harvested fruits from CL $4 \mathrm{mM}$ and SA $1.5 \mathrm{mM}$ sprayed plants after 10 days of storage ( 89.27 and $67.16 \%$ respectively) (Figure $2 \mathrm{a}$ ).

The best treatment to minimize fruit mass loss was CL $4 \mathrm{mM}$ and SA $1 \mathrm{mM}$ foliar spraying after 10 days of storage $(6.75 \%)$ (Figure $2 \mathrm{~b})$. Our findings with respect to the effect of CL and SA treatment and duration of storage on fruit mass loss showed that control fruits recorded maximum fruit mass loss after 30 days of storage $(19.54 \%)$. In this study, increasing of duration of storage led to a raise in fruit mass loss. Fruit mass loss is basically related to water loss and this essentially due to transpiration, which accounts for $90 \%$ of total mass loss and initially comes from the peel. Water loss adversely affects the quality and limits the economic post-harvest life of crops (Ennab et al., 2020). Our findings showed that foliar treatment led to a reduction in fruit mass loss. The result of this study is similar to the findings reported by Gupta et al. (2011). They reported that reduction in physiological mass loss in calcium sources treated fruits might be due to the maintenance of fruit firmness and tissue rigidity by decreasing the enzyme activity responsible for disintegration of cellular structure, which decreases the gaseous exchange.

According to ANOVA analysis, percent of fruit decay was conditioned by interaction between CL and SA foliar application and also main effect of duration of storage. Obtained results showed that the best treatment to decrease fruit decay was CL $4 \mathrm{mM}$ and SA $1 \mathrm{mM}$ foliar application (1.9\%) and 10 days storage led to the lowest
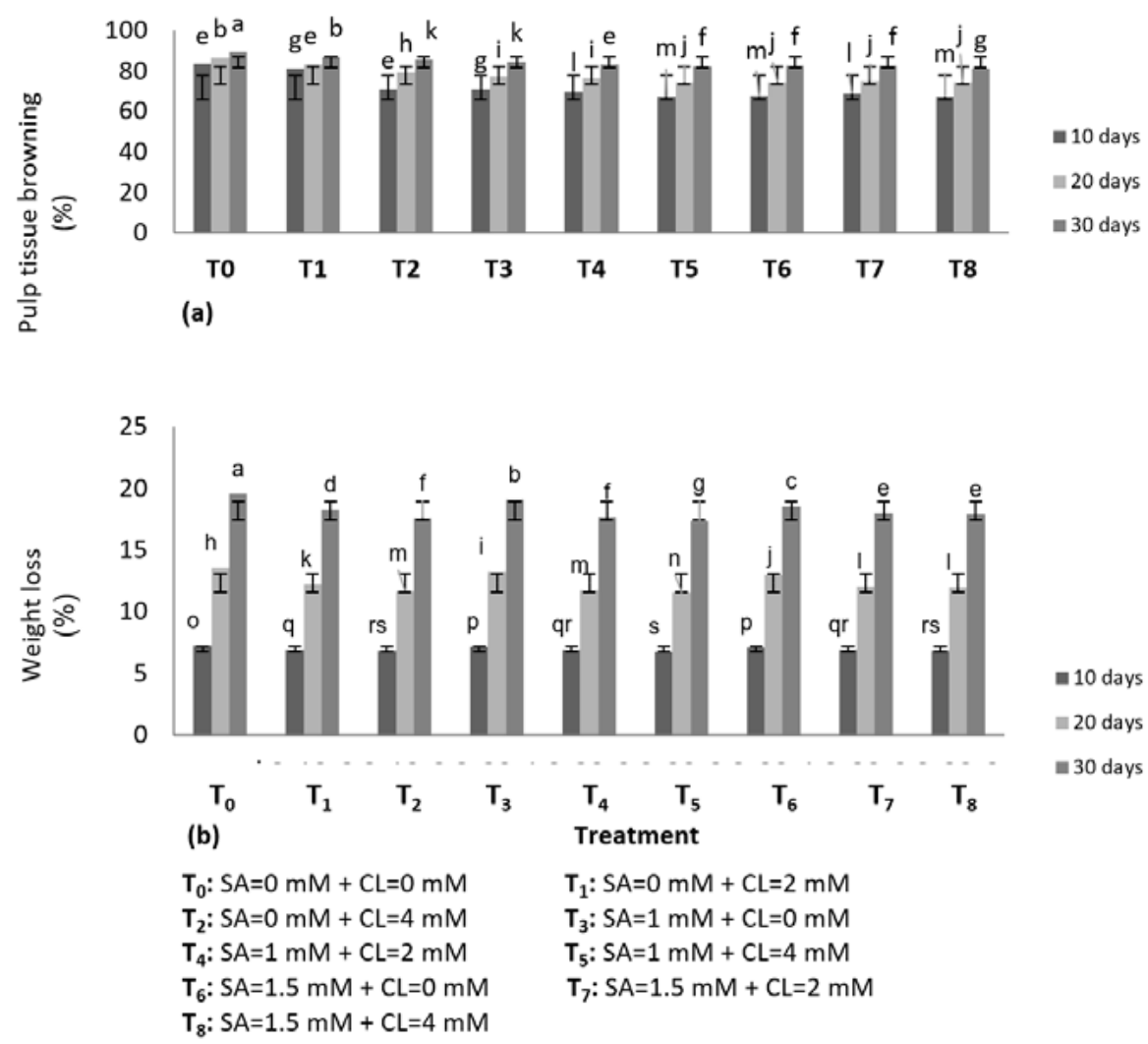

Figure 2: Effect of CL and SA foliar application and during of storage on: a browning percent and $b$ mass loss Values in columns for same variable followed by the same letter are not significantly different according to Duncan's multiple range test $(\mathrm{p} \leq 0.05)$ 
fruit decay percent $(1.28 \%$ ) (Table 6$)$. SA and calcium sources significantly reduced fruit decay of stored mandarins and sweet oranges due to enhancing the activity of antioxidant enzymes and improving resistance to fungal attack, the accumulation of $\mathrm{H}_{2} \mathrm{O}_{2}$ and defense-related metabolites like ornithine, threonine and polymethoxylated flavones (Zhu et al., 2016), and the anti-senescent effect that maintains fruit firmness, which eventually reduced microbial attack (Ahmed et al., 2013). Pre-harvest treatment of SA reduced post-harvest fruit decay and fungal diseases in melon (Huang et al., 2000), mango (Zainuri et al., 2001) and apple (Krishna et al., 2012).

Table 5: Effect of CL and SA foliar application and duration of storage on fruit decay after harvest

\begin{tabular}{|c|c|c|c|c|}
\hline SA concentration $(\mathrm{mM})$ & CL concentration $(\mathrm{mM})$ & Fruit decay (\%) & Duration of storage (day) & Fruit decay (\%) \\
\hline & 0 & $2.58 \mathrm{a}$ & 10 & $1.28 \mathrm{c}$ \\
\hline \multirow[t]{3}{*}{0} & 2 & $2.15 \mathrm{~cd}$ & 20 & $2.20 \mathrm{~b}$ \\
\hline & 4 & $2.03 \mathrm{de}$ & 30 & $3.10 \mathrm{a}$ \\
\hline & 0 & $2.36 \mathrm{~b}$ & & \\
\hline \multirow[t]{3}{*}{1} & 2 & $2.12 \mathrm{~cd}$ & & \\
\hline & 4 & $1.93 \mathrm{e}$ & & \\
\hline & 0 & $2.18 \mathrm{~cd}$ & & \\
\hline \multirow[t]{2}{*}{1.5} & 2 & $2.17 c d$ & & \\
\hline & 4 & $2.22 \mathrm{bc}$ & & \\
\hline
\end{tabular}

Values in columns for same variable followed by the same letter are not significantly different according to Duncan's multiple range test $(p \leq 0.05)$

\section{CONCLUSION}

Our results showed that foliar application of CL and SA can be useful and inexpensive treatment to improve growth parameters, physiological characteristics and post-harvest properties of eggplant fruit. The highest applied concentrations of CL and SA ( $4 \mathrm{mM}$ and $1.5 \mathrm{mM}$ ) foliar application led to the highest values in all of measured growth parameters such as leaf area, mass, number, diameter and length of fruit, height of plant and yield. Foliar spray of eggplants by CL at $4 \mathrm{mM}$ and $2 \mathrm{mM}$ and also SA at $1 \mathrm{mM}$ and $1.5 \mathrm{mM}$ led to a significant increase in photosynthetic pigments. The highest tissue firmness and ascorbic acid content of eggplant fruit was obtained by highest concentration foliar application of CL and SA. Also, negative effects of increasing of storage time on post-harvest properties decreased by employing of CL and SA foliar application. Using of higher concentrations of SA and CL as well as applying of other plant bio-regulator in eggplant cultivation is recommended for future researches.

\section{REFERENCES}

Ahmad, S., Singh, Z., Khan, A. S, \& Iqbal, Z. (2013). Preharvest applications of salicylic acid maintain the rind textural properties and reduce fruit rot and chilling injury of sweet orange during cold storage. Pakistan Journal of Agriculture Science, 50, 559-569.

Akhtar, A., Abbasi, N. A., \& Hussain, A. (2010). Effect of calcium chloride treatments on quality characteristics of Loquat fruit during storage. Pakistan Journal of Botany, 42, 181-188.

Almeida, P. H., Mógor, A. F., Ribeiro, A. Z., Heinrichs, J., \& Amano, E. (2016). Increase in lettuce (Lactuca sativa L.) production by foliar calcium application. Australian Journal of Basic and Applied Sciences, 10(1016), 161-167.

Arnon, A. N. (1967). Method of extraction of chlorophyll in the plants. Agronomy, 23, 112-121.

Arvanitoyannis, I., Khan, E. M., Evangelia, C. C., \& Bletsos, F. A. (2005). Effect of grafting and modified atmosphere packaging on eggplant parameters during storage. International Journal of Food Science \& Technology, 40(3), 311-322. https://doi.org/10.1111/j.1365-2621.2004.00919.x

Campestre, C., Marsilio, V., Lanza, B., Lezzi, C., \& Bianchi, G. (2002). Phenolic compounds and organic acids change in black oxidized table olives. Acta horticulturae, 586, 575578. https://doi.org/10.17660/ActaHortic.2002.586.120

Chandra, A., \& Bhatt, R. K. (1998). Biochemical and physiological response to salicylic acid in relation to the systemic acquired resistance. Photosynthetica, 35(2), 255-258. https:// doi.org/10.1023/A:1006966908357

Dong, C. X., Zhou, J. M., Fan, X. H., \& Wang, H. Y. (2004). Application methods of calcium supplements affect nutrient levels and calcium forms in mature tomato fruits. Journal of Plant Nutrition, 27, 1443-1455. https://doi.org/10.1081/ PLN-200025861

Elvwan, M. W. M., \& Hamahyomy, M. A. M. (2009). Improved 
productivity and quality assocated with salicylic acid application in greenhouse pepper. Scientia Horticulturae, 122, 521-526. https://doi.org/10.1016/j.scienta.2009.07.001

Ghahremani, Z., Mikaealzadeh, M., Barzegar, T., and Ranjbar M. E. (2020). Foliar application of ascorbic acid and gamma aminobutyric acid can improve important properties of deficit irrigated cucumber plants (Cucumis sativus $c v$. Us), Gesunde Pflanzen. https://doi.org/10.1007/s10343-02000530-6 https://doi.org/10.1007/s10343-020-00530-6

Ghassemi-Golezani, K., \& Farhangi-Abriz, S. (2018). Foliar sprays of salicylic acid and jasmonic acid stimulate $\mathrm{H}^{+}-$ ATPase activity of tonoplast, nutrient uptake and salt tolerance of soybean. Ecotoxicology and Environmental Safety, 166, 18-25. https://doi.org/10.1016/j.ecoenv.2018.09.059

Gupta, N., Jawandha ,S. K., \& Gill, P. S. (2011). Effect of calcium on cold storage and post-storage quality of peach. Food Science and Technology, 48(2), 225-229.

Hepler, P. K. (1994). The roll of calcium in cell division. Cell Calcium, 16(4), 322-330. https://doi.org/10.1007/s13197010-0116-z ttps://doi.org/10.1016/0143-4160(94)90096-5

Huang, Y., Deverall, B. J., Tang, W. H., Wang, W., \& Wu, F. W. (2000). Foliar application of acibenzolar-S-methyle and protection of postharvest rock melons and hami melon from disease. European Journal of Plant Pathology, 106, 651656. https://doi.org/10.1023/A:1008767719691

Javaid, K., \& Misgar, F. A. (2017). Effect of foliar application of salicylic acid and prohexadione-calcium on leaf nutrient content of apple cv. Red Delicious. Advance Research Journal of Multidisciplinary Discoveries, 20(6), 27-29.

Kader, A., \& Lindberg, S. (2010). Cytosolic calcium and pH signaling in plants under salinity stress. Plant Signal Behavior, 5, 233-238. https://doi.org/10.4161/psb.5.3.10740

Kalarani, M. K., Thangaraj, M., Sivakumar, R., \& Mallika, V. (2002). Effect of salicylic acid on tomato (Lycopersion esculentum) productivity. Field Crop Research Journal, 23, 486-492.

Karlidag, H., Yildirim, E., \& Turan, M. (2009a). Exogenous applications of salicylic acid affect quality and yield of strawberry grown under anti-frost heated greenhouse condition. Journal of Plant Nutrition and Soil Science, 172, 270-276. https://doi.org/10.1002/jpln.200800058

Karlidag, H., Yildirim, E., \& Turan, M. (2009b). Salicylic acid ameliorates the adverse effect of salt stress on strawberry. Scientia Agricola, 66, 180-187. https://doi.org/10.1590/ S0103-90162009000200006

Kaushik, P. (2019). Line $\times$ Tester analysis for morphological and fruit biochemical traits in eggplant (Solanum melongena L.) using wild relatives as testers. Agronomy, 9(4), 185-194. https://doi.org/10.3390/agronomy9040185

Kazemi, M. (2013a). Foliar application of salicylic acid and calcium on yield, yield component and chemical properties of strawberry. Bulletin of Environment, Pharmacology and Life Sciences, 2(11), 19-23.

Kazemi, M. (2013b). Response of cucumber plants to foliar application of calcium chloride and paclobutrazol under greenhouse conditions. Bulletin of Environment, Pharmacology and Life Sciences, 2(11), 15-18.

Kazemi, M., Aran, M., \& Zamani, S. (2011). Effect of calcium chloride and salicylic acid treatments on quality charac- teristics of kiwifruit (Actinidia Deliciosa) during storage. American Journal of Plant Physiology, 6(3), 183-189. https:// doi.org/10.3923/ajpp.2011.183.189

Khani, A., Barzegar, T., Nikbakht, J., \& Ghahremani, Z. (2020). Effect of foliar spray of calcium lactate on the growth, yield and biochemical attribute of lettuce (Lactuca sativa L.) under water deficit stress. Advances in Horticultural Science, 34(1), 11-24.

Kowalska, L., \& Smolen, S. (2012). Effect of foliar application of salicylic acid on the response of tomato plants to oxidative stress and salinity. Journal of Elementology, 18, 239-254. https://doi.org/10.5601/jelem.2013.18.2.04

Krishna, H., Das, B., Attri, B. L., Kumar, A., \& Ahmed, N. (2012). Interaction between different pre-harvest and postharvest treatments on shelf life extension of 'Oregon Spur' apple. Fruits, 67, 31-40. https://doi.org/10.1051/fruits/2011064

Mahajan, B. V. C., Gill, K. S., \& Dhaliwal, H. S. (2017). Effect of storage period on various physiological, biochemical and enzymatic parameters of guava (Psidium guajava L.) fruit. Journal of Experimental Biology and Agricultural Sciences, 5, 846-851. https://doi.org/10.18006/2017.5(6).846.851

Martin-Diana, A., Rico, D., Barry-Ryan, C., Jesu, M. F., Mulcahy, J., \& Gary, T. M. (2005). Comparison of calcium lactate with chlorine as a washing treatment for fresh-cut lettuce and carrots: quality and nutritional parameters. Food and Agriculture, 85(13), 2260-2268. https://doi.org/10.1002/ jsfa. 2254

Mohamed, A. K., \& Basalah, M. O. (2015). The active role of calcium chloride on growth and photosynthetic pigments of cowpea (Vigna unguiculata L.) under salinity stress conditions. American-Eurasian Journal of Agricultural \& Environmental Sciences, 15(10), 2011-2020.

Mustafavi, S. H., Badi, H. N., Sekara, A., \& Al, E. (2018). Polyamines and their possible mechanisms involved in plant physiological processes and elicitation of secondary metabolites. Acta Physiologiae Plantarum, 40, 102-112. https:// doi.org/10.1002/jsfa.2254

Paull, R. E., and Chen, N. J. 1989. Waxing and plastic wraps influence water-loss from papaya fruit during storage and ripening. Journal of American Society of Horticulture Science, 114, 937-942.

Rab, A., \& Haq, I. (2012). Foliar application of calcium chloride and borax influences plant growth, yield, and quality of tomato (Lycopersicon esculentum Mill.) fruit. Turkish Journal of Agriculture, 36, 695-701.

Raja, R. H. S., Bhat, Z. A., Malik, A. R., \& Shafi, R. H. (2015). Interrelationship between fruit quality and pre-harvest calcium chloride treatment on peach. International Journal of Agriculture, Environment and Biotechnology, 8(1), 103-109. https://doi.org/10.5958/2230-732X.2015.00014.5

Ranjbar, M. E., Olfati, J. A., \& Amani, M. (2017). Influence of enriched soaking water on shiitake mushroom yield and properties. Acta Agriculturae Slovenica, 109(3), 555-560. https://doi.org/10.14720/aas.2017.109.3.07

Shaarawi, S. A., Salem, A. S., Elmaghraby, I. M., \& ABD ElMoniem, E. A. (2016). Effect of salicylic Acid, calcium chloride and calcium lactate applications on quality attributes of minimally-processed 'Wonderful' pomegranate arils. 
Notulae Botanicae Horti Agrobotanici Cluj-Napoca, 44(2), 508-517. C https://doi.org/10.15835/nbha44210534

Uzunova, A., \& Popova, L. (2000). Effect of salicylic acid on leaf anatomy and chloroplast ultrastructure of barley plants. Photosynthetica, 38, 243-250. https://doi. org/10.1023/A:1007226116925

Vanderslice, J. T., Higgs, D. J., Hayes, J. M., \& Block, G. 1990. Ascorbic acid and dehydroascorbic acid content of foodaseaten. Journal of Food Composition and Analysis, 3, 105118. https://doi.org/10.1016/0889-1575(90)90018-H

Wang, L., Chen, S. H., Kong, W., Li, S. H., \& Archbold, D. (2006). Salicylic acid pretreatment alleviates chilling injury and affects the antioxidant system and heat shock proteins of peaches during cold storage. Postharvest Biology and Technology, 41, 244-251. https://doi.org/10.1016/j.postharvbio.2006.04.010

Yildirim, E., Turan, M., \& Guvenc, I. (2008). Effect of foliar salicylic acid applications on growth, chlorophyll and mineral content of cucumber (Cucumis sativus L.) grown under salt stress. Journal of Plant Nutrition, 31, 593-612. https://doi. org/10.1080/01904160801895118

Youssef, S., Abd Elhady, S., Abu El-Azm, N., \& El-Shinawy, M. (2017). Foliar application of salicylic acid and calcium chloride enhances growth and productivity of lettuce (Lactuca sativa). Egyptian Journal of Horticulture, 44(1), 1-16. https://doi.org/10.21608/ejoh.2017.892.1000

Zainuri, J. D. C., Wearing, A. H., Coates, L., \& Terry, L. (2001). Effects of phosphonate and salicylic acid treatments on anthracnose disease development and ripening of 'Kensington Pride' mango fruit. Australian Journal of Experimental Agriculture, 41, 805-813. https://doi.org/10.1071/EA99104

Zhu, F., Chen, J., Xiao X., Zhang, M., Yun, Z., \& Zeng, Y. (2016). Salicylic acid treatment reduces the rot of postharvest citrus fruit by inducing the accumulation of $\mathrm{H} 2 \mathrm{O} 2$, primary metabolites and lipophilic polymethoxylated flavones. Food Chemistry, 207, 68-74. https://doi.org/10.1016/j.foodchem.2016.03.077 